\title{
Eliasz Robakiewicz
}

Uniwersytet Warszawski

e-mail: erobakiewicz@gmail.com

\section{Dominacja bez hegemonii - pojęcie władzy w studiach postkolonialnych szkoły Subaltern Studies}

Słowa kluczowe: Subaltern Studies, studia postkolonialne, dominacja, hegemonia, władza, nacjonalizm

Subaltern Studies to powstały na początku lat osiemdziesiątych i działający do dziś projekt badawczy skupiający się wokół serii wydawniczej Subaltern Studies, która ma dziś już dziesięć tomów. Światową sławę zyskał wraz z wejściem do amerykańskiego świata akademickiego publikacją Selected Subaltern Studies w 1988 roku z przedmową już wówczas światowej sławy teoretyka studiów postkolonialnych, czyli Edwarda Saïda. Wyboru dokonali wspólnie Ranajit Guha oraz Gayatri Chakravorty Spivak. Guha jest uznawany za „ojca założyciela” grupy, natomiast Spivak za najbardziej rozpoznawalną postać, której esej Czy podporządkowani inni moga przemówić? zyskał status tekstu kanonicznego. Przedstawiciele i przedstawicielki tej szkoły wykładają w szeregu światowej sławy uczelniach wyższych. W niniejszym artykule przedstawiam analizę pojęcia władzy w książce Dominance without Hegemony Guhy, uznając ją za reprezentatywny przykład teorii postkolonialnej w wydaniu szkoły Subaltern Studies. Przedstawiam także krytykę amerykańskiego socjologa Vivka Chibbera, zgodnie z którą sformułowana przez Guhę teza o „specyficznie indyjskiej” drodze do kapitalizmu („dominacji bez hegemonii”), przeciwstawiona tej zachodniej, rozumiana jako nieudana formacja władzy demokratycznej, jest właśnie typową formą władzy w kapitalizmie. Typowa forma demokracji to dominacja oparta na systematycznym wykluczaniu klasy pracującej ze struktur władzy, wykluczenie 
to nie świadczy o nieistnieniu klasy pracującej, a jedynie o tym, że jest ona poddana dominacji klasowej.

\section{Pasywna rewolucja: odmienny bieg historii}

Nurt Subaltern Studies powstał ze sprzeciwu wobec elitarystycznej historiografii Indii z jednej strony oraz schematycznej i jałowej historiografii liberalnej oraz marksistowskiej z drugiej. Można by powiedzieć, że twórczynie i twórcy Subaltern Studies wpisywaliby się w szerszy nurt tak zwanej history from below czy people's history, który reprezentowali tacy wybitni historycy marksistowscy, jak E.P. Thompson, Christopher Hill czy Howard Zinn, którzy jednak nie chcieli zgodzić się na marksistowską teorię $\mathrm{w}$ formie, jaka była wówczas dominująca ${ }^{1}$. W latach osiemdziesiątych, po zwycięstwie Rewolucji Październikowej oraz wygranej Mao w Chinach, czy później, wraz z rozpadem systemu kolonialnego, było jasne, że pojęcie „klasa robotnicza" stawało się wysoce problematyczne, a walki polityczne są często walkami z kapitalizmem w formie imperializmu, a nie walkami w obrębie struktur wysoko rozwiniętego kapitalizmu². Wielkie rewolucje XX wieku wydawały się raczej rewolucjami chłopskimi, w których brali udział robotnicy, wojsko i inteligencja, niż rewolucjami, w których robotnicy pełnią wiodącą rolę. Pogląd taki wydawał się tym bardziej wiarygodny w okresie zimnowojennej walki ,socjalizmu” z „kapitalizmem”, czyli dwóch bloków państw, gdzie państwa Trzeciego Świata stawały się często prze-

1 Thompson został pod koniec lat siedemdziesiątych mianowany prezesem Indyjskiego Kongresu Historyków. Jak wskazuje Rajnarayan Chandavarkar, idee Thompsona, a w szczególności jego rozumienie klasy jako tworu historycznego i określonego przez formy doświadczenia i świadomości, wpłynęły mocno na indyjskich historyków. Jednak problem, który stał przed nimi w tym okresie, był dość konwencjonalny - zderzenie imperializmu z nacjonalizmem, a wykorzystanie dokonań Thompsona dość proste. Proces „tworzenia brytyjskiej klasy pracującej” został zastąpiony procesem „tworzenia indyjskiego narodu”. Chandavarkar uważa jednak, że wpływ Thompsona wbrew pozorom był bardzo pobieżny, a świadczą o tym m.in. trzy problemy: 1) proste, linearne i mechanistyczne rozumienie kultury sprawiało, że ekonomia była rozumiana jako siła deterministyczna; 2) w przeciwieństwie do Thompsona nie analizowano dogłębnie państwa, zakładając, że jest monolityczną opresyjną siłą; 3) esencjalizacją praktyk i tradycji kulturowych niepozwalającą włączyć analizy kultury w szersze problemy. $Z$ czasem wpływ Thompsonowskiego stylu analizowania w rozumieniu Subaltern Studies form doświadczeń nieudanego procesu „stawania się klasą” ustąpiły Foucaultowskim wpływom analizy dyskursu i rozumności, które pojawiły się wraz z wzrostem znaczenia Edwarda Saïda dla nurtu. R. Chandavarkar, 'The Making of the Working Class: E.P. Thompson and Indian History', w: Mapping Subaltern Studies and the Postcolonial, red. V. Chaturvedi, New York 2012, s. 50-65.

2 Neil Lazarus i Rashmi Varma twierdzą, że „pesymistyczny ton” i zwrot ku ruchom ludowym (popular movements) obecny w powstających na początku lat osiemdziesiątych studiach postkolonialnych zbiega się z ostateczną porażką ruchów wyzwoleńczych Trzeciego Świata i ogólnym zwrotem społeczeństw kapitalistycznego centrum przeciwko tym ruchom. Na temat zależności studiów postkolonialnych i marksizmu zob. N. Lazarus, R. Varma, Marxism and Postcolonial Studies, w: Criticial Companion to Contemporary Marxism, red. J. Bidet, S. Kouvelakis, Leiden 2008. 
strzenią tarć między blokami³. W samych Indiach kwestia podmiotowości w historii domagała się ponownego przemyślenia szczególnie w świetle dominującej historiografii liberalnej, w której jedynymi podmiotami byli liderzy nacjonalistycznego ruchu, tacy jak Gandhi czy Nehru. Inspirację dla teoretyków pochodzących z kraju, gdzie w dalszym ciągu przytłaczająca część ludności była pochodzenia chłopskiego, stanowił Antonio Gramsci, również pochodzący z kraju z wysokim udziałem chłopstwa w populacji, który w swoich Dziennikach więziennych posługiwał się pojęciem grup ,podporządkowanych” (subaltern) ${ }^{4}$. Teoria Gramsciego była z wielu powodów bardzo atrakcyjną drogą teoretycznego wyjścia poza marksizm i liberalizm. Jak przekonamy się później, schemat teoretyczny określany przez Guhę jako „dominacja bez hegemonii”, stosowany do wyjaśnienia historii modernizacji i zdobycia niepodległości Indii (wyjścia z kolonializmu), ma bardzo wiele wspólnego z pojęciem „,pasywnej rewolucji” którego użył Gramsci, by określić proces uzyskania niepodległości przez Włochy. Risorgimento Gramsci określał jako pasywną rewolucję, ponieważ gdy brak było masowego poparcia dla rewolucji, burżuazja przejęła kontrolę nad biegiem wydarzeń. Skutkiem takiej pasywnej (czy odgórnej) rewolucji było nie w pełni zintegrowane państwo trzymane głównie siłą państwa Piemontus.

Zgodnie z diagnozą i krytyką Rosalind O'Hanlon ${ }^{6}$ projekt Subaltern Studies zawiera $\mathrm{w}$ sobie fundamentalną trudność typową dla projektów naukowych krajów peryferyjnych $\mathrm{w}$ drugiej połowie XX wieku, dotyczącą zarówno samego materiału badawczego, pozycji naukowca, jak i samego pojęcia „reprezentacji” w nauce. Trudność ta pojawia się na wielu poziomach, często mniej lub bardziej świadomie skonceptualizowana na różne sposoby. Ma ona wymiar historyczny i materialny w postaci samej historii Indii, dyskursywno-teoretyczny i historiograficzny w postaci dążenia do stworzenia historii Indii niezależnej od narracji stworzonej na Zachodzie, wymiar filozoficzno-społeczny, czyli dążenie do opisania form podmiotowości niezależnych od zachodnich koncepcji (w tym podmiotowości samego naukowca). Wszystkie te aspekty mają także swoje powiązanie z krytyką kapitalizmu, ponieważ wprowadzanie kapitalistycznych stosunków produkcji jest utożsamiane z westernizacją. Problem stosunku do kapitalizmu jest jednocześnie w dużo bardziej widoczny sposób

3 T. Brennan, Subaltern Stakes, w: The Debate on Postcolonial Theory and the Specter of Capital, red. R. Warren, New York 2017; B. Robbins, Subaltern-Speak, w: The Debate on Postcolonial Theory and the Specter of Capital, red. R. Warren. New York 2017, s. 101-103.

4 Gramsci posługiwał się terminem ,grupa podporządkowana” zamiast ,proletariat” czy „filozofia praxis” zamiast „marksizm”, żeby ominąć cenzurę, co jednak nie znaczy, że przesunięcia są jedynie leksykalne. D. Arnold, Gramsci and Peasant Subalternity in India, w: Mapping Subaltern Studies and the Postcolonial, red. V. Chaturvedi, New York 2012, s. 33.

5 Ibidem, s. 45.

6 N. Lazarus, R. Varma, Marxism..., s. 319-321; R. O'Hanlon, Recovering the Subject: Subaltern Studies and Histores of Resistance in Colonial South Asia, w: Mapping Subaltern Studies and the Postcolonial, red. V. Chaturvedi, New York 2012, s. 73, s. 79, s. 91-98. 
niż w krajach dominujących problemem nacjonalizmu. Z perspektywy teoretyków kraju Trzeciego Świata kapitalizm jawi się nie jako struktura produkcji w obrębie społeczeństwa, tylko jako zewnętrzna siła mająca wymiar ekonomiczny, polityczny i kulturowy.

Wysoki wzrost gospodarczy łączący się z wystąpieniami wywłaszczanego przemocą chłopstwa stanowił kontekst dla rozważań teoretycznych w początkowych latach rozwoju grupy ${ }^{7}$. Nieustającym już od niemal 50 lat rządom, jak się wydawało, ,jedynej” partii Indii, czyli słynnego Indyjskiego Kongresu Narodowego, towarzyszyła spajająca dyskursywnie społeczeństwo historia tworząca narrację jedności narodowej zbudowanej pod wpływem wybitnych jednostek mówiących głosem narodu. Z pewnością przełomowym wydarzeniem był kryzys i wprowadzenie stanu wyjątkowego przez Indirę Gandhi w latach 1975-1977 postrzegane jako historyczny moment załamania się systemu demokratycznego. To przekonanie o istnieniu jednolitego głosu narodu i jego dyskursywnej reprezentacji chcieli w swoich badaniach podważyć twórcy Subaltern Studies.

\section{Widmo imperializmu}

W niniejszym opracowaniu chciałbym zająć się aktualnym w debatach teoretycznych problemem założeń teoretycznych grupy dotyczących przekształceń relacji władzy ustanowionych wraz z przekształceniami form kapitalizmu. W tym przypadku kluczową sprawą jest przemyślenie specyficznej formy politycznej, w jakiej rozwijał się w Indiach na przestrzeni XIX i XX wieku kapitalizm, czyli imperializmu brytyjskiego, a także konsekwencji, jakie miała dla przemiany i ustanowienia niezależnego państwa Indii taka forma „narodzin kapitalizmu”. Oczywiście kwestii tej nie jestem w stanie rozstrzygnąć z perspektywy sporów historycznych. Skromniejszy cel, jaki sobie stawiam, to w pierwszej części artykułu przedstawienie argumentu, jaki przedstawił wybitny historyk Guha, określającego formę władzy w kolonialnych i postkolonialnych Indiach. Ramy historyczne dla Guhy wyznaczają okres od brytyjskiego panowania (Raj) do zdobycia niepodległości w 1947 roku. Drugą część artykułu poświęcę rekonstrukcji krytyki argumentacji Guhy, która odbiła się szerokim echem w kręgach akademickich ${ }^{8}$, jaką przedstawił w swojej książce Postcolonial Theory

7 T. Brennan, Subaltern Stakes..., V. Chibber, Postcolonial Theory and the Specter of Capital, New York 2013, s. 28-35.

8 Między innymi książce zostało poświęcone w 2014 r. sympozjum opublikowane pierwotnie w „Journal of World-Systems Research”, które zostało przedrukowane w wydanej w 2017 r. książce: R. Warren, The Debate on Postcolonial Theory and the Specter of Capital, New York 2017. 
and the Spectre of Capital historyk i socjolog Chibber ${ }^{9}$. Książka ta nie doczekała się w Polsce szerszej dyskusji ${ }^{10}$, choć z pewnością została dostrzeżona ${ }^{11}$.

\section{Dominacja bez hegemonii}

Główna teza książki Guhy zawarta już na samym początku książki Dominance without Hegemony: History and Power in Colonial India wydanej w 1997 roku jest zasadniczo powtórzeniem tezy zawartej już w artykule On Some Aspects of the Historiography of Colonial India, który ukazał się po raz pierwszy w 1982 roku w pierwszym tomie Subaltern Studies I: Writings on South Asian History and Society. Można zatem uznać, że jest to teza o podstawowym znaczeniu dla badań grup podporządkowanych sformułowana przez czołowego przedstawiciela nurtu.

Zacznijmy od bardzo podstawowego pytania: co pozwala nam mówić o grupach podporządkowanych czy też „zdominowanych”? Badaczki Subaltern Studies, chcąc podważyć dominujące „elitarystyczne” interpretacje historii Indii, podają w wątpliwość istnienie jednolitej sfery polityki zarówno w epoce kolonialnej (XV-XIX w.) oraz walki o niepodległość, jak i po jej uzyskaniu (XX w.), gdzie w epoce kolonialnej jednorodną sferę polityki ma tworzyć kolonizatorska działalność Wielkiej Brytanii, realizując „cywilizacyjną misję” w Indiach, a w przypadku okresu walki o niepodległość i czasów niepodległego państwa są to nacjonalistyczne elity, które doprowadziły Indie do niepodległości.

Rządy elit są określone jako „hegemoniczne”, czyli takie, w których konsensus (czy perswazja) między klasami ma przewagę nad przymusem czy przemocą. W odwrotnym przypadku, przewagi przemocy nad konsensusem czy perswazją, mamy do czynienia z „dominacją”. Niemniej jak będzie dowodził Guha, rządów opartych na hegemonii nigdy w Indiach nie było. Dlatego też wbrew temu, co przedstawia kolonialna i nacjonalistyczna historiografia, były to rządy dominacji opartej na przemocy i dyscyplinowaniu grup podporządkowanych, które nigdy nie były włączone w tworzenie rządów za pomocą konsensusu. Taka forma rządów, nieudanej hegemonii, zostaje nazwana „dominacją bez hegemonii”.

9 Chibber otrzymał za swoją książkę w 2014 r. nagrodę „PEWS Book Award” (jest to nagroda przyznawana przez American Sociological Association dla wybitnych prac z dziedzin ekonomii politycznej oraz teorii systemów-światów). J. Skinner, Postcolonial Theory and the Specter of Capital awarded PEWS Book Award, http://www.versobooks.com/blogs/1635-postcolonialtheory-and-the-specter-of-capital-awarded-pews-book-award.

10 Krótkie wprowadzenie do badań nurtu Subaltern Studies: P. Borek, „Europejskie źródła indyjskiego projektu. Charakterystyka grupy Subaltern Studies, „Źródła Humanistyki Europejskiej” 2014, nr 7.

11 R. Poniat, Czy ktoś nie został (spost)kolonizowany? Czyli o pożytku z szerokich pojęć, „Pogranicze. Studia Społeczne” 2013, nr 22; W.J. Burszta, Monokultura i mediatyzacja. W strone kulturoznawstwa krytycznego, „Przegląd kulturoznawczy” 2014, nr 20; J. Bednarek, Akumulacja pierwotna i czasowości kapitalizmu, „Praktyka Teoretyczna” 2015, nr 16. 
Tak wygląda pierwsza, mało kontrowersyjna część argumentu Guhy. Jednak zakłada ona również drugi element, czyli zestawienie rządów burżuazji w Europie oraz w kolonialnych Indiach. Pojęcie władzy jest nierozerwalnie związane z pojęciem kolonializmu ${ }^{12}$. Z zestawienia tego wynika, że te dwie formy rządów są niemal swoimi przeciwieństwami. W Europie burżuazyjne rewolucje wprowadziły rządy hegemoniczne, podczas gdy w kolonialnych Indiach, mimo usilnych prób stworzenia ideologicznych obrazów takich rządów, realnie nigdy nie udało się ich wprowadzić. Istnieje fundamentalna różnica między kolonialnymi Indiami a Europą. Jak można wywnioskować z wypowiedzi Guhy, jest to różnica między państwem i narodem w pełni uformowanym jako jedność i państwem nieudanym czy nieuformowanym oraz podzielonym ${ }^{13}$. O „niedokończonym” charakterze modernizacji, nigdy nieosiągniętej hegemonii świadczy właśnie podstawowe dla całych Subaltern Studies stwierdzenie o niezdolności włączenia grup podporządkowanych do polityki przez elity i wynikająca $\mathrm{z}$ tego autonomia działań politycznych tychże grup. Autonomiczne grupy podporządkowane musiały być włączone do polityki siłą przez elity najpierw kolonialne, potem nacjonalistyczne, przez przemoc i dyscyplinę, czyli dominację.

W tym miejscu od razu warto zaznaczyć jedną ważną rzecz, która jest niejasna, ale i symptomatyczna dla problemu, jaki uwidacznia się w badaniach Subaltern Studies. Argument ten zresztą pojawia się w recenzji książki Chibbera autorstwa Parthy Chatterjee (jednego z trzech głównych obiektów krytyki książki Chibbera) ${ }^{14}$ jako forma obrony Guhy. Dotyczy on niejasności, czy sformułowana tu teza o fundamentalnej różnicy Wschód (Indie, peryferia)/Zachód (Europa, centrum) określa jedynie sferę

12 Czy w posunięciu tej tezy dużo dalej to kolonializm ujawnia „prawdziwą” naturę władzy kapitalistycznej. W interpretacjach postoperaistycznych oznacza, że to pierwotna czy - jak ją nazywa Massimo De Angelis - ,prymarna akumulacja” ujawnia naturę stosunków kapitalistycznych (polityczny i arbitralny charakter separacji bezpośrednich producentów od środków produkcji) i nie jest etapem w dziejach kapitalizmu, ma charakter ciągły. Z drugiej strony Guha wydaje się twierdzić, że jest ona „,anomalią” w strukturze kapitalistycznej władzy, jej nieprawidłową czy niedorozwiniętą postacią. Dyskusja ta jednak ujawnia trudność, która jest moim przedmiotem zainteresowania $\mathrm{w}$ artykule, tzn. czy schemat interpretacyjny „,dominacji bez hegemonii” jest użyteczny do rozwiązania problemu rozważanego przez postoperaistów za pomocą pojęcia prymitywnej czy prymarnej akumulacji, czy też nie. W związku z tym także, czy pojęcia „hegemonii” i „dominacji” są użyteczne do tego celu, czy też nie. Czy też w najogólniejszym sformułowaniu: czy polityczne warunki reprodukcji stosunków kapitalistycznych są reprodukowane wyłącznie na gruncie autonomicznej sfery życia grup podporządkowanych, czy też nie. M. De Angelis, Marx and Primitive Accumulation: The Continuous Character of Capital's „Enclosures”, „The Commoner” 2001, no. 2; W. Bonefeld, The Permanence of Primitive Accumulation: Commodity Fetishism and Social Constitution, „The Commoner” 2001, no. 2; S. Mezzadra, Tak zwana akumulacja pierwotna, w: Marks. Nowe perspektywy, thum. S. Królak, Warszawa 2014, s. 37-84.

13 R. Guha, „On Some Aspects of the Historiography of Colonial India, w: Mapping Subaltern Studies and the Postcolonial, red. V. Chaturvedi, New York 2012, s. 6.

14 P. Chatterjee, Subaltern Studies and Capital, „Economic \& Political Weekly” 2012, no. 37; V. Chibber, A Response to Partha Chatterjee, w: The Debate on Postcolonial Theory and the Specter of Capital, red. R. Warren, New York 2017. 
dyskursywną, czy także rzeczywistość. Nie jest pewne, czy twierdzenie to dotyczy ideologicznego obrazu Europy i Indii, czy zarówno obrazu, jak i stanu faktycznego. Na pewno można mieć jasność co do twierdzenia Guhy, że obie interesujące go dyskursywne formacje, czyli nacjonalistyczna i kolonizatorska, miały fałszywy charakter (nie były prawdziwą hegemonią). Niejasna jednak jest kwestia, czy hegemonia w Europie miała realny, czy również tylko dyskursywny charakter (czy to tylko twór ideologiczny, czy też forma rządów). Guha z jednej strony wskazuje na analizy Marksa, który sam dostrzegał różnicę między tym, jak widzi siebie burżuazja, a stanem faktycznym (szczególnie w Niemczech, gdzie relacjonował nieudaną rewolucję 1848 r. dla „Neue Rheinische Zeitung”), z drugiej jednak stwierdza, że iluzje te ostatecznie rozwiane zostają właśnie w koloniach, gdzie ujawnia się siłowy charakter kapitalistycznej władzy. Jednak jak się zdaje, ta przemoc nie jest interpretowana jako normalna cecha kapitalistycznej władzy, tylko przejaw jej zwyrodniałej formy. Powstaje ciekawe pytanie, czy dla krytycznej teoretyczki może istnieć „poprawna/wzorcowa/niesprzeczna" forma kapitalizmu? Czy też ujmując problem z perspektywy postkolonialnej: czy kapitalizm wchodzi z konieczności w sprzeczność ze wszystkimi niekapitalistycznymi formami społecznymi i czy sprzeczność ta powinna być rozumiana źródłowo właśnie jako relacja kolonialnej dominacji? ${ }^{15}$

Starając się odpowiedzieć na pytanie o charakter „fałszywości” historiografii kolonialnej oraz nacjonalistycznej, możemy spróbować sformułować dwie odpowiedzi na to pytanie. Hegemonia jest fałszywa, ponieważ nie powiela wzorca ,prawdziwej hegemonii" (np. rewolucji francuskiej) albo dlatego, że w ogóle hegemonia jest tylko ideologicznym wyrazem jakiejś bardziej podstawowej sfery. Żeby rozjaśnić ten zagmatwany problem, odwołam się do schematu relacji władzy przedstawionego w książce Guhy ${ }^{16}$. Schemat ten jego zdaniem wynika z błędu, który pojawia się u Gramsciego, czyli przeciwstawienia hegemonii i dominacji ${ }^{17}$. Władza dzieli się na dominację i podporządkowanie, a te z kolei dzielą się: dominacja na przemoc oraz perswazję (nastawioną na konsensus), natomiast podporządkowanie - na kolaborację oraz opór. Widać zatem z powyższego schematu, że dominacja i hegemonia są różnymi częściami struktury władzy. Można powiedzieć, że schemat ten opiera się na założeniu o kontinuum różnic jakościowych tej samej władzy - od nagiej przemocy do indoktrynacji ideologicznej czy działalności deliberatywnej ze strony dominujących oraz drugiego kontinuum od zbrojnego oporu do spolegliwej kolaboracji ze strony zdominowanych. Jeżeli tak wygląda struktura pojęcia władzy będącego

15 B. Robbins, Subaltern-Speak; V. Chibber, Reply to Bruce Robbins, w: The Debate on Postcolonial Theory and the Specter of Capital, red. R. Warren, New York 2017.

16 R. Guha, Dominance without Hegemony, London 1997, s. 20-23.

17 Jednak silnie opiera się na myśleniu Gramsciego w kategoriach dialektycznych par „władza/ opór”, „siła/konsensus”, „hegemonia/podporządkowanie”, D. Arnold, Gramsci and Peasant..., s. 33. 
pojęciem pierwotnym względem pojęć dominacji i hegemonii jako modalności władzy, to powyższe trudności dają się ująć w dużo jaśniejszy sposób. Można rozumieć strategię Guhy w następujący sposób: dominacja i podporządkowanie występują we wszystkich społeczeństwach, lecz mają zawsze swój specyficzny kształt. Tym, co różni Indie od demokracji Europy, jest fakt, że dominacja musiała oprzeć się przemocy $i$ to tym określonym formom przemocy została podporządkowana kolaboracja indyjskich elit. W efekcie sfera perswazji nie stała się sferą politycznej reprezentacji całości społeczeństwa, tylko została zagospodarowana początkowo przez kolonialny dyskurs maskujący przemoc ideologią „misji cywilizacyjnej”, później przez jej powtórzoną i zinterioryzowaną wersję nacjonalistyczną. Tu to indyjskie elity niosą tym razem misję budowy niepodległego państwa (zajmując strukturalną pozycję kolonizatora). W całej tej relacji władzy brakuje oczywiście oporu podporządkowanych. To właśnie podstawowa teza Subaltern Studies: sfera oporu grup podporządkowanych jest autonomiczna względem całej kolonialnej czy postkolonialnej struktury władzy. Wyciągnijmy z tego twierdzenia oczywisty wniosek. O autonomii grup podporządkowanych świadczy ich wyłączenie ze sfery perswazji, czyli niemożliwość utworzenia hegemonii przez klasy dominujące, nie natomiast, jak można by się spodziewać, niezależność od aparatu przymusu. Grupy podporządkowane nie są włączone w kolaborację z klasami dominującymi, przez co nie widzą w nich reprezentantów własnych interesów.

Co ciekawe, nie znajdziemy w książce Guhy analiz form wyzysku i przemocy, tylko analizę idiomów. Pierwszy z nich to ,idiom porządku” wprowadzanego przez kolonialną władzę oraz odpowiadający mu po stronie indyjskich kolaborantów „idiom Danda” wiążący autorytarną władzę z półfeudalnymi praktykami dominacji. Kolejnym idiomem jest ,idiom postępu” oraz ponownie odpowiadający mu ,idiom Dharmy" wiążący hierarchiczną władzę z mitycznym ideałem harmonijnego zespolenia społeczeństwa. Trzecią parą idiomów są ,idiom podporządkowania” (szacunku dla słusznej hierarchii) oraz feudalnej i religijnej tradycji Bhakti ustanawiającej tradycyjny hierarchiczny porządek społeczny.

Jak wskazuje Guha, idiomy te dzielą się na dwa zespoły: „liberalny i brytyjski”" oraz „prekolonialny, prekapitalistyczny i indyjski”, które są źródłem form władzy we wszystkich aspektach (przemocy, perswazji, kolaboracji, a także nawet oporu) ${ }^{18}$. Taka forma rządów tworzona przez sparowanie przemocy brytyjskiej władzy kolonialnej z jej neofeudalnymi indyjskimi odpowiednikami świadczy zdaniem Guhy o porażce „uniwersalistycznej tendencji kapitalizmu”19, czyli wytworzenia specy-

18 R. Guha, Dominance..., s. 61.

19 Temat ten zostaje szerzej omówiony w rozdziale piątym, gdzie przedmiotem krytyki obok Guhy jest Dipesh Chakrabarty i jego projekt ,prowincjonalizacji Europy”. Por. H.W. Sewell, On Vivek Chibber's Postcolonial Theory and the Specter of Capital, w: The Debate on Postcolonial Theory and the Specter of Capital, red. R. Warren, New York 2017. Chakrabarty czyni z bę- 
ficznej formy polityczności wraz z pojawieniem się kapitalistycznego sposobu produkcji. Porażka ta skutkuje wytworzeniem despotycznego państwa będącego niemal odwróceniem państwa burżuazyjnego, gdzie panuje przynajmniej formalna równość, stosunek pracy najemnej jest dominujący, a politykę uprawia się za pomocą perswazji i konsensusu. Historiografia brytyjska starała się ten charakter ukryć za pomocą wskazanych idiomów, usiłując wykazać, że choć „cywilizacyjna misja” nie została osiągnięta, to Wielka Brytania jest jedyną siłą, która mogłaby Indie tą drogą poprowadzić. Niemniej narracja prowadzona w tej historiografii nigdy nie była historią narodową opartą na nowoczesnej liberalnej koncepcji państwa. Zarówno edukacja, jak i produkcja wiedzy służyła jedynie kolonialnemu modelowi panowania i osiągania zysków ${ }^{20}$. Warto tutaj zaznaczyć ciekawą prawidłowość. Guha na podstawie obecności pewnych form dyskursu politycznego (tak rozumiem ,idiom”) wnioskuje o nieobecności innych form dyskursu politycznego (burżuazyjnej hegemonii), a z tej nieobecności wnioskuje o nie-kapitalistycznym czy nie-do-końca-kapitalistycznym charakterze aparatu państwowego w Indiach. Aparacie, który zamiast jak w Europie przezwyciężyć feudalne pozostałości, wszedł z nimi we współpracę, a nawet je wzmocnił ${ }^{21}$. Z kolei z kształtu aparatu państwowego jako politycznej podstawy wyzysku ekonomicznego wnioskuje się o kształcie całego społeczeństwa.

W przedstawionej powyżej analizie zdumiewający jest jeden fakt. Argument mający na celu udowodnienie panowania dominacji opiera się na analizie form dyskursu. Oczywiście historyk zawsze bada dokumenty i porządkuje je w określony sposób, ale nie chodzi tu o sam ten fakt, a raczej o to, że przedmiotem zainteresowania są jedynie sposoby formułowania wypowiedzi (a nie np. kształt i funkcjonowanie aparatów represji). Nawet wsparty tezą o siłowym charakterze jego funkcjonowania zinstytucjonalizowanej przemocy czy w lżejszej wersji dyscypliny - sam materiał

dącego przedmiotem mojej uwagi w opracowaniu podziału na dwie formy władzy podstawę swojego projektu, nazywając historię uniwersalizujących i homogenizujących stosunków kapitalistycznych „historią 1”, natomiast historię grup podporządkowanych władzy, w rozumieniu Guhy „dominacji bez hegemonii”, „historią 2”. Ta druga to historia autonomicznego oporu grup podporządkowanych. Chibber przeciwstawia takiemu rozumieniu uniwersalizmu obecne$\mathrm{mu} \mathrm{w}$ kapitalistycznych stosunkach produkcji marksistowskie rozumienie, zgodnie z którym uniwersalizacji zostaje poddany sposób produkcji i reprodukcji społeczeństwa kapitalistycznego, czyli proces akumulacji kapitału oznaczający zależność od rynku zarówno kapitalistów, jak i robotników. Sama analiza Guhy świetnie pokazuje, w jaki sposób różne formy władzy i kultury mogą pozostawać w różnych stosunkach do procesu akumulacji kapitału. Kapitaliści mogą odwoływać się, zgodnie z analizą Guhy, do retoryki „postępu” (improvment), jak i do retoryki tradycjonalistycznej i religijnej takiej jak dharma. Podobnie powyższe strategie mogą być wykorzystane na korzyść klasy pracującej. Ich znaczenie polityczne jest zrelatywizowane do stosunku, który może takie znaczenie nieść. Jedno i to samo zjawisko społeczne może być w tym samym czasie dla różnych aktorów społecznych funkcjonalne na różne, często przeciwstawne sposoby. Problem ten jest szerzej omówiony, choć z pozycji broniącej Chakrabarty'ego, w artykule: J. Bednarek, Akumulacja pierwotna...

20 R. Guha, Dominance..., s. 165.

21 Ibidem, s. 178. 
badawczy wydaje się nasuwać co najmniej dwuznaczne wnioski. Po pierwsze, wskazuje raczej na głębokie uwikłanie grup podporządkowanych w politykę, a po drugie, niemożliwość redukcji tak rozumianej władzy do pojęć hegemonii czy dominacji, a już na pewno nie wykazania dominacji bez hegemonii.

\section{Widmo kapitalizmu}

Przejdźmy teraz do rekonstrukcji i krytyki argumentu Guhy dotyczącego struktury władzy w kolonialnych Indiach, będącego jednocześnie sporem o teoretyczne ujęcie tego problemu. Problem sformułowania Guhy jest podwójny. Poddając krytyce perspektywę liberalnej historiografii Indii, w której stwierdza się, że uniwersalistyczna tendencja kapitału, której wyznacznikiem są hegemoniczne rządy burżuazji, nigdy nie miały miejsca w Indiach, jednocześnie uznaje, że w Europie rządy burżuazji miały taki kształt. Co więcej - określając władzę burżuazji europejskiej jako hegemoniczną, sprawia, że uniwersalizm jest jednostronnie przypisany do działań burżuazji, wykluczając możliwość sprawczości ruchów robotniczych i innych ruchów oddolnych. W przypadku braku takiej klasy i presji z jej strony niemożliwe było stworzenie ogólnonarodowego ruchu wyzwolenia.

Zgodnie z moją rekonstrukcją pojęcia władzy zawartego w książce Guhy można przypuszczać, że różnica ta jest wyróżniona na podstawie omówionej struktury (czteroelementowego schematu władzy). Polega ona, jak już powiedziałem, na różnicy „składu” władzy w Europie - jest to znacząca przewaga konsensusu i perswazji nad przymusem i dominacją. Jednak jak zauważa Chibber, pojęcie władzy przedstawione przez Guhę jest de facto pojęciem politycznej władzy burżuazji (w języku Althussera ideologicznych i opresyjnych aparatów państwa), gdzie określone formy produkcji zostają założone jako będące podstawą analizy, lecz pozbawione znaczenia ${ }^{22}$. Wyciągnijmy tymczasowy wniosek co do określenia różnicy grup podporządkowanych w Indiach. Odmienność przedmiotu badań Subaltern Studies, czyli grup podporządkowanych, jest określona przez kompozycję politycznej władzy burżuazji. W zależności od kompozycji tej władzy różny kształt ma polityczna działalność grup podporządkowanych. W przypadku burżuazji europejskiej jest to w większym stopniu dyskursywno-jurydyczno-kulturowe uczestnictwo w sferze polityki i w dużo mniejszym stopniu opór (w coraz większym stopniu znormalizowana kolaboracja i konsensus, targowanie się o pozycję w systemie). W przypadku burżuazji kolonialnej i nacjonalistycznej w koloniach jest to zasadniczo autonomiczny opór i brak akceptacji burżuazyjnej sfery polityki. Chibber twierdzi, że Guha utożsamia uniwersalizującą tendencję kapitału w rozumieniu raczej politycznym niż ekonomicznym z działaniem burżuazji.

22 V. Chibber, Postcolonial Theory and the Specter of Capital. New York 2013, s. 35-36. 
Powstaje pytanie, czy stosunki społeczne są wynikiem powiązania danych grup w szerszym procesie politycznym, czy efektem działalności jednej bądź drugiej grupy. Uważam, że pod pojęciem ,autonomii” grup podporządkowanych czy klasy pracującej kryje się przekonanie o niepolitycznym charakterze ich działalności oraz o tym, że w pewnym momencie historii działalność polityczna klasy pracującej czy też grup podporządkowanych została w ten lub inny sposób zamknięta lub zakończona. Drogę do walki politycznej klasy pracującej zamyka w tym przypadku kształt władzy kolonialnej opartej na pół-feudalnych pół-kolonizatorskich metodach przemocy i represji niemogących być podstawą typowych form walki klasowej, które wytworzyła klasa pracująca w Europie. Taki kształt władzy nie zamyka jednak drogi rozwoju burżuazji. Jak się zdaje, politycznym celem nie jest rewolucja robotników, którzy poniekąd „mieli już swoją szansę”, tylko nowej kosmopolitycznej burżuazji epoki globalizacji. Ujawnia się tutaj strukturalna wada tej teorii władzy - tylko burżuazja dysponuje siłą, grupy podporządkowane mogą jedynie stawiać opór. Problem tkwi tutaj w samym rozumieniu pojęcia władzy. U podstaw tego pojęcia nie znajduje się wcale prosta konstatacja, że można rządzić ,albo mieczem, albo słowem”, tylko zinternalizowana teoretycznie różnica między centrum a koloniami.

Aby obalić twierdzenie o hegemonicznej roli burżuazji w dwóch rewolucjach, które za przykłady sukcesu (modelowe hegemonie) podaje Guha, angielskiej rewolucji 1648 roku oraz rewolucji francuskiej 1789 roku, należy właśnie nie tyle wykazać ich siłowy charakter, co wskazać, że jako „rewolucje burżuazyjne” (w tym sensie) nie miały miejsca. Mam przez to na myśli, że jeżeli za ,rewolucję burżuazyjną” należy uznać przejęcie władzy, w której hegemonia przeważa dominację, i obalenie przez to porządku feudalnego, to nie da się interpretować w ten sposób wspomnianych powyżej wydarzeń ${ }^{23}$.

W przypadku rewolucji angielskiej, przedstawiając już same wnioski z analizy, Chibber twierdzi, że wydarzenia lat czterdziestych XVII wieku należy raczej interpretować jako wojnę domową, której stawką była kwestia, jaki kapitalizm będzie panować w Anglii, a nie kwestia przezwyciężenia feudalizmu, którego i tak już nie było (istniała wczesna forma kapitalizmu określana mianem ,agrarnego kapitalizmu”). Był to spór klasy agrarnych kapitalistów z królem, w którym udział radykalnych ruchów oddolnych był traktowany raczej jako zło konieczne w walce (w momencie, gdy elity podzieliły się na dwa obozy), a poszerzenie praw szerokich mas jako niewyobrażalny koszmar gorszy nawet od wygranej króla i umocnienia dążeń do absolutyzmu. Jednak celem burżuazji było zarówno niedozwolenie na wykształcenie się aparatu państwowego monarchii absolutnej w Anglii, jak i niedopuszczenie niższych warstw do sfery polityki. Było to zamknięcie polityki w postaci dyscyplinarnego

23 V. Chibber, Confronting Postcolonial Theory: A Response to Critics, w: The Debate on Postcolonial Theory and the Specter of Capital, red. R.Warren, New York 2017; idem, Reply to Bruce Robbins, H.W. Sewell, On Vivek Chibber's Postcolonial Theory... 
państwa z potężnym aparatem fiskalno-militarnym oraz oligarchiczną formą rządów (stanowiących podstawy akumulacji kapitalistycznej w Anglii, gdzie ideologia wolnego rynku jest jedynie konsekwencją tej silnej pozycji narodowej). Jako przykład „uniwersalistycznych” tendencji niemających nic wspólnego z ową „,burżuazyjną rewolucją" Chibber podaje oddolne ruchy lewelerów oraz diggerów. Rewolucja ta nie ukonstytuowała sfery hegemonii obejmującej całe społeczeństwo, a właśnie wykluczającą formę, gdzie parlament służył do artykulacji interesu klasy dominującej.

W przypadku rewolucji francuskiej Chibber dowodzi, że to, co zwykle określa się mianem burżuazji dążącej do uzyskania praw pozwalających jej na rozwój produkcji kapitalistycznej, nie ma wiele wspólnego z przedstawicielami trzeciego stanu, którzy w ogromnej mierze składali się z reprezentantów wolnych zawodów, wykształconego mieszczaństwa, kupców i sklepikarzy ${ }^{24}$ (Chibber 2012, 69). Przedstawiał więc raczej specyficzną grupę, ale pracowników niż pracodawców (jeżeli mamy nazywać tę grupę burżuazją, to na pewno tak rozumiana burżuazja nie jest tożsama z klasą kapitalistów). Niemniej pomimo tej istotnej różnicy wskazującej, jak szerokim i rozmytym pojęciem jest „burżuazja”, osiągnięcia trzeciego stanu były, podobnie jak w przypadku rewolucji angielskiej, paktem wśród elit, będących podobnie jak w tamtym przypadku pod silną presją ruchów ludowych i na pewnym etapie partii najsilniej z nimi powiązanej (jakobinów). Jej celem nie było obalenie monarchii czy społeczeństwa stanowego, ale poprawa sytuacji określonej grupy społecznej. Przedstawiciele trzeciego stanu reprezentowali samych siebie, nie postulując obalenia feudalizmu czy jakiejkolwiek poprawy dla klas podporządkowanych. Jeżeli pojawiła się w tych wydarzeniach jakaś ,uniwersalizująca tendencja”, to wiązała się ona z mobilizacją klas podporządkowanych i ich presją, która od początku była ważnym, jeżeli nie decydującym czynnikiem.

Argument nie polega tutaj na wykazywaniu, że jedynymi demokratyzującymi i „uniwersalizującymi” siłami były siły ludowe, tylko na wskazaniu ich znaczenia dla całości stosunków społecznych. Jeżeli wynik tych wydarzeń można uznać za wkroczenie klas podporządkowanych do polityki w danym okresie historycznym, to było ono wynikiem walki (zarówno militarnej, politycznej, jak i dyskursywnej), a nie utworzenia hegemonii. Burżuazja została zmuszona do stworzenia sojuszu z klasami podporządkowanymi w obu przypadkach właśnie widmem przegranej walki zbrojnej z przeciwnikiem.

Po nawet tak krótkiej rekonstrukcji, gdy patrzymy na opisywane przez Guhę wydarzenia historyczne, wydają się one dość dobrze pasować do przedstawionej przez Chibbera narracji: „Podsumowując, dominacja bez hegemonii - tak jak definiuje ją Guha - nie jest jakąś aberracją powstałą w postkolonialnym świecie czy też wyni-

24 V. Chibber, Postcolonial Theory..., s. 69. 
kiem nieudanej rewolucji burżuazyjnej. Taka właśnie jest i zawsze była normalna forma burżuazyjnej władzy"25 (Chibber 2012, 91).

Zadziwiające jest to, że choć rekonstrukcja Chibbera dotyczy samych podstaw argumentacji Guhy i zasadniczo pomija w swoich rozważaniach ogromną część książki poświęconą władzy kolonialnej i formom oporu przeciw niej, czyli sprzed 1947 roku, to gdy przyjrzeć się tej części książki Guhy, która te formy omawia, to jedynie wzmacnia ona argumentację Chibbera. Cały pomysł odwrócenia struktury władzy opiera się na fałszywej wizji historii Europy. Perspektywa przedstawiana przez Guhę w dużej mierze pokrywa się z tym, w jaki sposób widzieli te wydarzenia liberalni historycy XIX wieku, a wraz z nimi także i Marks, dla którego byli oni głównym źródłem informacji na ten temat ${ }^{26}$, choć starał się on w swojej późniejszej twórczości poddać te wydarzenia reinterpretacji. Taka perspektywa i aparat teoretyczny uniemożliwiają postawienie pytania o sukcesy i niepowodzenia ruchów grup podporządkowanych. Są one z jednej strony bezsilne, ponieważ w ogóle nie pojawia się konceptualna możliwość posiadania przez nie władzy, oraz skazane na porażkę, gdyż miarą ich działalności jest sprzeczny wewnętrznie cel klasy nad nimi dominującej. W takiej sytuacji ,autonomia” jawi się jako bardzo problematyczne pojęcie, które sankcjonuje konceptualne przesunięcie z problematyki „separacji od środków produkcji” do „separacji od środków wypowiedzi politycznej”. Sprawia, że podstawowym zadaniem teoretyka zdaje się wydawanie sądów normatywnych, które praktyki były „skorumpowaną” formą podporządkowaną przymusowi dominującej klasy, a które były „prawdziwie” autonomicznymi praktykami oporu grup podporządkowanych, wskutek czego miarą ich autentyczności jest skala ich porażki i izolacji ${ }^{27}$.

Warto na koniec odnieść się do argumentu, który Chakrabarty podnosił zarówno w Prowincjonalizacji Europy ${ }^{28}$, jak i później w recenzji Postcolonial Theory and the Spectre of Capital Partha Chatterjee ${ }^{29}$, czyli twierdzenia, że książka Chibbera opiera się na jednym wielkim nieporozumieniu: nie chodziło nigdy o realne stosunki społeczne w Europie, tylko o ich „idee” czy też ideologiczną reprezentację w historiografii ${ }^{30}$. Twierdzenie to jest podparte tezą, że choć taki obraz może być nieprawdziwy i mieć tylko dyskursywny charakter, to może jednocześnie wywierać realne skutki na rzeczywistość, co uwidacznia się w tym, w jaki sposób „idiomy” badane przez Guhę miały w nim oparcie. Nie jestem równie pewny co Chibber co do przekonania, że za-

25 Ibidem, s. 91.

26 Ibidem, s. 95.

27 Por. V. Murthy, Looking for Resistance in All the Wrong Places? Chibber, Chakrabarty, and a Tale of Two Histories, w: The Debate on Postcolonial Theory and the Specter of Capital, red. R. Warren, New York 2017.

28 D. Chakrabarty, Prowincjonalizacja Europy, Poznań 2011, s. 16-20, s. 33-46, s. 59-64, s. 79-90, s. 295-319.

29 P. Chatterjee, Subaltern Studies...

30 V. Chibber, Postcolonial Theory..., s. 127-129. 
równo Guha, jak i Chakrabarty po prostu uznawali, że obraz Europy był traktowany jako adekwatny, a powyższa obrona jest jedynie strategią retoryczną. Uważam, że właśnie ta niejasność jest konstytutywna dla argumentu Guhy. Sądząc po tym, w jaki sposób argumentacji tej broni Gyan Prakash ${ }^{31}$ czy Chakrabarty, czyniąc z tego błędu już explicite fundament swojego projektu, była ona prawdopodobnie uznawana za wyraz krytycyzmu. Nie należy też zapominać, że choć Chibber oskarża Guhę o popadanie w konserwatywny sposób myślenia, to konserwatyzm ten przesiąkł do teorii Subaltern Studies prawdopodobnie właśnie za pośrednictwem marksizmu, czego Chibber nie chce przyznać - z jednej strony przez deterministyczne schematy, z drugiej przez obecną w części marksistowskiej historiografii tendencję do akceptacji liberalnej wizji historii pod nazwą ,historycznej roli burżuazji” jako etapu rozwoju „ku socjalizmowi”.

Podstawy argumentacji analizy przedstawionej w Dominance without Hegemony są bardzo mgliste i ogólnikowo opisane, niemniej zasadniczo, pomijając dwa fundamentalne błędy, czyli 1) ukryte założenie o determinowaniu gospodarki przez aparat państwowy, w szczególności jego ideologiczne aparaty; 2) ukryte i prawdopodobnie niecelowe rozmycie rozróżnienia na rzeczywisty proces historyczny i jego

$31 \mathrm{~W}$ artykule Writing Post-Orientalist Histories of the Third World: Perspectives from Indian Historiography Gyan Prakash nazywa takie podejście „postfundacjonalistycznym”, odrzucającym zarówno ideologiczne obrazy „całościowej historii”, jak i „pęknięte” obrazy historii jako walki klas marksizmu (które także zachowują w sobie ideologię oświeceniową w postaci totalizującego pojęcia „sposobu produkcji”). Dla Prakasha realnym odpowiednikiem filozoficznej idei niemożliwości totalności jest dominacja, która w fundamentalny sposób określa historię i społeczeństwo Indii i której można przeciwstawić jedynie kontrhegemonię (projekt odwrócenia dominacji). Artykuł ten wywołał polemikę ze strony Rosalind O'Hanlon i Davida Washbrooka, wyrażając krytykę w podobnym tonie do krytyki Chibbera, lecz skupiającej się na pojęciu (samo)reprezentacji. Prakasha odpowiada w artykule Can the "Subaltern” Ride? A Reply to O'Hanlon and Washbrook, którego tytuł, nawiązując do tytułu słynnego eseju Spivak, zadaje pytanie o pozycję naukowca krajów peryferyjnych, pytając czy można ,jechać (ride) na dwóch koniach jednocześnie", tzn. korzystać z analiz marksistowskich i poststrukturalistycznych. Choć jego odpowiedź wydaje mi się wysoce niezadowalająca, to zwraca on uwagę na ważny problem nieobecny w marksistowskich krytykach Rosalind O’Hanlon, Toma Brassa, Sumita Sarkara czy wreszcie samego Viveka Chibbera, czyli pozycji podmiotowej samego autora. Marksiści oczywiście twierdzą, że nie jest to tak istotna kwestia w porównaniu z treścią i zadaniami samej teorii, jednak nie da się ukryć, że w książce Chibbera ta tematyka w ogóle nie pojawia się. G. Prakash, Writing Post-Orientalist Histories of the Third World: Perspectives from Indian Historiography, w: Mapping Subaltern Studies and the Postcolonial, red. V. Chaturvedi, New York 2012; idem, Can the "Subaltern" Ride? A Reply to O'Hanlon and Washbrook, w: Mapping Subaltern Studies and the Postcolonial, red. V. Chaturvedi, New York 2012; R. O'Hanlon, Recovering the Subject: Subaltern Studies and Histores of Resistance in Colonial South Asia, w: Mapping Subaltern Studies and the Postcolonial, red. V. Chaturvedi, New York 2012; R. O'Hanlon, D. Washbrook, After Orientalism: Culture, Criticism and Politics in the Third World, w: Mapping Subaltern Studies and the Postcolonial, red. V. Chaturvedi, New York 2012; T. Brass, Moral Economist, Subalterns, New Social Movements and the (Re-) Emergence of a (Post-) Modernized (Middle) Peasant, w: Mapping Subaltern Studies and the Postcolonial, red. V. Chaturvedi, New York 2012; S. Sarkar, The Decline of the Subaltern in Subaltern Studies, w: Mapping Subaltern Studies and the Postcolonial, red. V. Chaturvedi, New York 2012. 
dyskursywne reprezentacje, można stwierdzić, że argumentacja Guhy jest bardzo konsekwentna. Korzystając przede wszystkim z „migotliwego” znaczenia władzy, które na przemian znaczy coś zupełnie rzeczywistego i konstrukcję dyskursywną, analiza idiomów jako form łączących w niewyjaśniony sposób oba znaczenia władzy wydaje się spójną konceptualizacją. Jak sądzę, dowodzi to, tak jak i dalszy rozwój nurtu Subaltern Studies, że nie był to błąd czy nieścisłość w argumentacji. Jest to nieudana próba wyjścia poza wulgarny marksizm, o ile w latach siedemdziesiątych i osiemdziesiątych zupełnie zrozumiała i wpisująca się w szersze tendencje w naukach humanistycznych, to już w 1997 w roku wydania Dominance without Hegemony czy w 2000, czyli roku wydania Prowincjonalizacji Europy, nabierająca innego znaczenia. W kolejnych tomach Subaltern Studies widoczny był zwrot ku badaniom literaturoznawczym i kulturowym z coraz mniejszym udziałem samych grup podporządkowanych ${ }^{32}$.

\section{Historyczny kapitalizm (polemiki i komentarze)}

Co ciekawe, jak wskazuje w swoim eseju George Steinmetz ${ }^{33}$, argumentację analogiczną do konstrukcji „,dominacji bez hegemonii” można odnaleźć w innych środowiskach intelektualnych. Steinmetz wskazuje na tak zwaną teorię Sonderweg, zgodnie z którą trajektoria rozwoju Niemiec (przede wszystkim modernizacji) różni się od wszystkich innych krajów, a przyczyną tej odmienności była specyficzna burżuazja niemiecka. Z początku teza ta miała pozytywny wydźwięk, natomiast po II wojnie światowej służyła raczej za schemat pozwalający wskazać przyczyny powstania nazizmu „właśnie w Niemczech”. Klasa ta miałby różnić się mocnym przywiązaniem do kultury i form organizacji feudalnych, antymodernizmu i pesymizmu kulturowego, a także przede wszystkim metody utrzymywania władzy przez silny aparat represji (dominacji). Przykład ten służy Steinmetzowi wskazaniu, że zarówno w Niemczech, jak i w Indiach (i tu zgadza się z Chibberem) taki rozwój nie jest nietypowy, a kapitalizm jest jak najbardziej kompatybilny z niedemokratycznymi formami rządów. Bardzo podobna debata teoretyczna dotycząca rozwoju kultury politycznej i form władzy w Wielkiej Brytanii, nazywana Narin-Anderson thesis (od nazwisk dwóch teoretyków, którzy ją sformułowali), odbyła się na łamach „New Left Review” w latach siedemdziesiątych XX wieku ${ }^{34}$. Debata ta również dotyczyła wpływu specyficznej kultury politycznej burżuazji (hegemonii, gdzie konflikt między burżuazją i arystokracją nie był silny) na słaby rozwój demokratycznych struktur władzy w Wielkiej

32 S. Sarkar, The Decline...

33 G. Steinmetz, On the Articulation of Marxist and Non-Marxist Theory in Colonial Historiography, w: The Debate on Postcolonial Theory and the Specter of Capital, red. R. Warren, New York 2017, s. 141.

34 E. Meiksins Wood, The Pristine Culture of Capitalism: A Historical Essay on Old Regimes and Modern States, New York 2015, s. 14. 
Brytanii. Poddaję ocenie Czytelnika, na ile problematyka ta możliwa jest do zrekonstruowania w polskim dyskursie teoretycznym dotyczącym modernizacji i roli burżuazji. Jak sądzę, dwie głośne książki stanowiące próby syntetycznej wykładni procesu modernizacji Polski (choć dotyczące różnych okresów historycznych), czyli Fantomowe ciało króla Jana Sowy ${ }^{35}$ oraz esej Prześniona rewolucja Andrzeja Lede$\mathrm{ra}^{36}$, stanowią dobry punkt wyjścia. Przedstawione powyżej przykłady służą tylko za wskazówki, iż jest to problem teoretyczny niemający jedynie lokalnego charakteru. Dokładniejsze jego zbadanie wymagałoby osobnego szerszego omówienia.

Jak konkluduje Chibber, Subaltern Studies reanimuje typową narrację orientalistyczną jedynie ze zmienionymi wartościowaniami moralnymi ${ }^{37}$. Jednak jeżeli zawiesić moralną krytykę kapitalizmu zawartą w tej teorii, wizja staje się niezwykle jasna: kapitał zachodni jest absolutnie dominującą formą produkcji, towarzyszące mu formy władzy i kultury wypierają zawsze formy władzy i kultury grup podporządkowanych. Walka tych grup była skazana od początku na porażkę (nic nie pomoże nazwanie jej autonomią) i nie przyniosła żadnych wymiernych efektów. Kultura grup podporządkowanych stanowi zasób kulturowy (prekapitalistyczne artefakty kulturowe bez realnego wpływu na rzeczywistość) w walce o hegemonię globalnych elit (w ramach usprawiedliwienia: elit neoliberalnej lewicy czy też lewicy „zbękarconego keyensizmu"). Ustanawianie hegemonii jest jednoznaczne w takim przypadku z byciem „w centrum”, a wysuwanie żądań politycznych z byciem na peryferiach. Jeżeli przyjąć by wnioski przeciwne, to znaczy że teoria postkolonialna, obnażając dominację w koloniach, obnaża także dominację w centrum, co również wydaje się dość popularną opcją (wystarczy porównać postoperaistyczną dyskusję na temat „prymitywnej akumulacji”), to ciężko wskazać, w jaki sposób krytyka ideologii miałaby pomóc w przełamaniu dominacji, skoro sama koncepcja dominacji zakłada, że decydującą rolę ma w niej przemoc, a nie perswazja. Dominacji z definicji nie da się przełamać argumentacją, tylko siłą. Jeżeli bronić by dalej tej tezy, twierdząc, że jest to teoria rewolucyjnej praktyki wskazująca na istniejące praktyki oporu, to powstaje pytanie, jakie praktyki wskazuje ta teoria - praktykę akademika czy intelektualisty w najbardziej przychylnej interpretacji, gdyż analizowane praktyki są związane z tworzeniem wiedzy. Nie można się nie zgodzić, że taka krytyka „dyskursów władzy" jest potrzebna i może być skuteczna, jednak zakrawa na absurd, by w niej realizowała się cała teoria krytyczna i co więcej - z niej czerpała swoje rozumienie, czym jest kapitalizm i w jaki sposób z nim walczyć. Nie chodzi tu o wyliczankę, kto jest bardziej, a kto mniej „częścią systemu”, tylko o tematykę i przedmiot badań. Tu-

35 J. Sowa, Fantomowe ciało króla, Kraków 2011.

36 A. Leder, Prześniona rewolucja: ćwiczenie z logiki historycznej, Warszawa 2014.

37 A.S. Purakayastha, Postcolonial Theory and the Specter of Capital, „Journal of Postcolonial Writing" 2014, no. 50. 
taj trzeba po części przyznać rację nieco prymitywnej marksistowskiej krytyce ${ }^{38}$, że znaczenie przedmiotu badań jest dużo większe niż ,pozycji podmiotowej” badacza, co nie znaczy, że pozycja badacza jest kwestią nieistotną. Nie wydaje się też trafna strategia argumentacyjna przeciw takim zarzutom, jaką przyjęła Spivak w swojej recenzji Postcolonial Theory and the Specter of Capital ${ }^{39}$. Wskazuje ona, że tak jak członkowie Subaltern Studies są częścią pewnej formacji intelektualnej związanej z centrum, tak samo Chibber jest związany ze środowiskiem „New Left Review” nazywanym przez Spivak pogardliwie „małym brytyjskim marksizmem”. Cała recenzja jest dość kuriozalna, ważne jest jednak, żeby zauważyć tutaj jedną rzecz. Dla teorii krytycznej kryteria prawdziwości muszą pochodzić spoza samej teorii (niezależnie jak szeroko będziemy postrzegać „dyskursywizację” rzeczywistości). To, czy teoretyczka jest aktywistką wśród ludności wiejskiej Bengalu czy brytyjską panią profesor, może mieć olbrzymie znaczenie dla teorii, którą tworzy, jednak nie należy od razu wyciągać wniosku, że pozycja badaczki decyduje o wartości tworzonej przez nią teorii. Analogicznie nie należy się sprzeczać z twierdzeniem, że wiedza pozostaje zawsze w pewnej relacji z władzą, co nie znaczy krytyka wiedzy czy ideologii musi mieć jakiekolwiek przełożenie na krytykę władzy. Fakt, że można tworzyć krytyczną teorię wiedzy, nie zmienia w niczym faktu, że wiedza jest z jednej strony produkowana w kapitalistyczny sposób, a z drugiej - że jej produkcja jest podporządkowana kapitałowi. Analizy ,jedynie dyskursywne”, takie jak analiza Guhy, pokazują, że nie ma niczego takiego jak analiza ,jedynie dyskursywna”.

\section{DOMINATION WITHOUT HEGEMONY - THE CONCEPT OF POWER IN POST-COLONIAL STUDIES AT THE SCHOOL OF SUBALTERN STUDIES}

\section{Summary}

Subaltern Studies is a research project that has been created in the early 80 's and is still active. It was formed around the Subaltern Studies publishing series, which has up until now ten volumes. It gained worldwide recognition with the entry into the American academic world by the publication of Selected Subaltern Studies in 1988 with the preface of the then world-renown post-colonial studies theorist, Edward Saïd. The selection was made jointly by

38 T. Brass, Moral Economist...; M. Schwartz, Capitalist Development, Structural Constraint, and Human Agency in the Global South: An Appreciation of Vivek Chibber's Postcolonial Theory and the Specter of Capital, w: The Debate on Postcolonial Theory and the Specter of Capital, red. R. Warren, New York 2017.

39 G.Ch. Spivak, Postcolonial Theory and the Specter of Capital, „Cambridge Review of International Affairs” 2014, no. 27; V. Chibber, Making Sense of Postcolonial Theory. A Response to Gayatri Chakravorty Spivak, w: The Debate on Postcolonial Theory and the Specter of Capital, red. R. Warren, New York 2017. 
Ranajit Guha and Gayatri Chakravorty Spivak. Guha is considered the "founding father" of the group, while Spivak is the most recognizable character whose essay Can the subordinates speak? gained the status of a canonical text. His representatives and representatives lecture in a number of world-renowned universities. In my article I analyze concept of power in Guha's book Dominance without hegemony, recognizing it as a representative example of postcolonial theory of the Subaltern Studies project. I also present the criticism of Guha's concept of power developed by American sociologist Vivek Chibber, according to which the thesis formulated by Guha about the "specifically Indian" road to capitalism ("domination without hegemony"), understood as an unsuccessful formation of democratic power, contrasted with this western successful road, is a typical form of power under capitalism. A typical form of democracy in capitalism is dominance based on the systematic exclusion of the working class from the power structures, this exclusion does not indicate the non-existence of the working class, but only that it is subjected to class domination.

Keywords: Subaltern Studies, postcolonial studies, dominance, hegemony, power, nationalism 